\title{
Effect of combined propofol-sevoflurane anesthesia on immune function in pediatric patients with acute lymphoblastic leukemia
}

\author{
NIU DI ${ }^{1 *}$, YUE GUO $^{2 *}$ and NANNAN DING ${ }^{3}$ \\ Departments of ${ }^{1}$ Pediatrics and ${ }^{2}$ Oncology, Xiangyang No. 1 People's Hospital \\ Affiliated to Hubei University of Medicine, Xiangyang, Hubei 441000; ${ }^{3}$ Department of Pharmacy, \\ Xiangyang Central Hospital Affiliated to Hubei University of Arts and Science, Xiangyang, Hubei 441021, P.R. China
}

Received August 30, 2018; Accepted March 28, 2019

DOI: $10.3892 / \mathrm{ol} .2019 .10316$

\begin{abstract}
Effect of combined propofol-sevoflurane anesthesia on immune function in pediatric patients with acute lymphoblastic leukemia (ALL) was investigated. A retrospective analysis was performed on 150 pediatric patients with ALL who were admitted to Xiangyang No. 1 People's Hospital Affiliated to Hubei University of Medicine from May 2014 to October 2017. All eligible patients were treated with intrathecal chemotherapy and were randomized into three groups according to the type of anesthesia used: group A, propofol used only; group B, sevoflurane used only; and group C, combined propofol and sevoflurane used. Venous blood samples were drawn, respectively, at $30 \mathrm{~min}$ before anesthesia (T1) and $24 \mathrm{~h}$ after anesthesia (T2). Flow cytometry was used to detect the percentages of T- and B-cell subsets, as well as the ratio of Th1/Th2 in T helper cells (Th cells). Serum levels of IFN $\gamma$, IL- 4 and TGF- $\beta$ were measured using enzyme-linked immunosorbent assay. At T2, the percentages of $\mathrm{CD}^{+}, \mathrm{CD}^{+}$and $\mathrm{CD} 19^{+}$cells in group $\mathrm{C}$ were significantly higher than those in groups $\mathrm{A}$ and $\mathrm{B}(\mathrm{P}<0.05)$. The percentage of $\mathrm{CD}^{+}$cells in group $\mathrm{C}$ was significantly higher than that in group $\mathrm{A}(\mathrm{P}<0.05)$. At $\mathrm{T} 2$, the percentages of Th1 and Th2 cells and the Th1/Th2 ratio in group $\mathrm{C}$ were higher than those in groups $\mathrm{A}$ and $\mathrm{B}(\mathrm{P}<0.05)$. At T2, IL-4 level in group $\mathrm{C}$ was significantly higher than that in group $\mathrm{A}(\mathrm{P}<0.05)$, while TGF- $\beta$ level was significantly lower $(\mathrm{P}<0.05)$. The IFN $\gamma$ level in group $\mathrm{C}$ was higher than those in groups $\mathrm{A}$ and $\mathrm{B}(\mathrm{P}<0.05)$. The IFN $\gamma /$ IL- 4 ratio in group $C$ was higher than that in
\end{abstract}

Correspondence to: Dr Nannan Ding, Department of Pharmacy, Xiangyang Central Hospital Affiliated to Hubei University of Arts and Science, 136 Jingzhou Street, Xiangyang, Hubei 441021, P.R. China

E-mail:nnv2gr@163.com; dd1mol@163.com

"Contributed equally

Key words: combined propofol-sevoflurane anesthesia, pediatric acute lymphoblastic leukemia, immune function, T cells, B cells, $\mathrm{T}$ helper cells group A $(\mathrm{P}<0.05)$. Combined propofol-sevoflurane anesthesia was more beneficial to the recovery of $\mathrm{T} / \mathrm{B}$ cell subset activity, to the alleviation of immunosuppression, and the suppression of ALL progression, compared to the sole use of propofol or sevoflurane.

\section{Introduction}

Acute lymphoblastic leukemia (ALL) is a malignant tumor characterized by the abnormal proliferation of $\mathrm{T}$ - and B-lymphoid progenitor cells in the bone marrow, which may cause hematopoietic dysfunction and may invade extramedullary tissues. ALL is the most common malignant hematological tumor with the highest mortality rate among children (1). It can lead to disordered $\mathrm{T}$ cell ratio in the blood system, T cell dysfunction, as well as NK cell immune dysfunction, causing body's immune function, especially cellular immunity, to be seriously impaired (2). ALL not only invades the hematopoietic system, but also damages the body's immune system, leading to an abnormal Th1/Th2 ratio in $\mathrm{T}$ helper cells (Th cells), increased presence of $\mathrm{CD} 4{ }^{+} \mathrm{CD} 25^{+}$ Treg cells, and increased expression of immunosuppressive factors, such as TGF- $\beta$ (3). Sudden onset of symptoms and rapid disease progression are associated with ALL. If not treated in time, ALL can be fatal within weeks or months (4). At present, the cause of ALL remains unclear, but genetic factors, such as Down's syndrome and related gene mutation/fusion, as well as environmental factors, such as radiation exposure and benzene homologues, are risk factors (5). Because the early symptoms of ALL are mostly fever, bruises and other atypical presentations, it is often overlooked, especially in children (6). Although new medical treatments, such as immunotherapy, have been proposed, the most common treatment methods for ALL are chemotherapy with continuous induction of remission, radiotherapy and intensive combination therapy. Chemotherapy is still the preferred treatment. Intrathecal chemotherapy, in which chemotherapy drugs are administered through a lumbar puncture, is most routinely prescribed. Bone marrow biopsy is regarded as a reliable tool for ALL diagnosis $(7,8)$. Anesthesia and sedation are required for bone marrow biopsy, stem cell transplantation and intrathecal injection, as pediatric patients' 
have poor compliance and self-control. Moreover, pediatric patients have a lower tolerance to anesthesia and operation than healthy children and adults due to their incomplete development of various physical functions and attenuated immune function caused by ALL (9). Therefore, the outcomes of anesthesia and sedation, as well as the impact on patients' immune function, play an important role in prognosis.

Sevoflurane, a new type of inhalational anesthetic agent, has a low blood/gas partition coefficient and does not cause respiratory tract irritation. The patient has a short recovery time after anesthesia. Sevoflurane has high anesthesia efficiency and can assist in muscle relaxation in addition to sedation $(10,11)$. Propofol, a fast-acting systemic intravenous anesthetic agent, has the characteristics of quick recovery after anesthesia, mild gastrointestinal reaction, and low cumulative effect after continuous administration (12). Whitlow et al (13) found that local anesthetics combined with propofol produced safe and effective analgesia and sedation in patients who underwent lumbar puncture. It was reported that the choice of anesthetic drugs affected not only the anesthetic outcome but also the proliferation of cancer cells and the immune function (14). Flouda et al (15) reported that sevoflurane and propofol had certain effects on cognitive and immune function in elderly patients with gastric cancer, and the effect on cognitive function was minimal. In this study, the effect of combined propofol-sevoflurane anesthesia on the immune function of pediatric patients with ALL was explored in order to improve the efficacy and safety of anesthesia, as well as the prognosis and the survival rate of these patients.

\section{Patients and methods}

Patients. A retrospective analysis was performed on the clinical data of 150 pediatric patients with ALL who were newly diagnosed by bone marrow biopsy from May 2014 to October 2017. All patients received intrathecal chemotherapy after anesthesia was induced. Patients were separated into three groups. In group A, 50 patients were anesthetized with propofol only. In group B, 50 patients were anesthetized with sevoflurane only. In group C, 50 patients were anesthetized with combined propofol-sevoflurane. Patients who met the following inclusion criteria were eligible for this study: i) patients who met the diagnostic criteria for ALL, which included the bone marrow smear demonstrating $\geq 30 \%$ lymphoblasts and prolymphocytes; ii) patients aged $\leq 14$ years; and iii) patients who were administered $10 \mathrm{mg}$ of methotrexate (first dose $5 \mathrm{mg}$ ) combined with $2 \mathrm{mg}$ of dexamethasone in saline through intrathecal injection. Patients who met the following criteria were excluded from this study: i) patients who had other cancers; ii) patients who had other autoimmune diseases; iii) patients who had been vaccinated in the previous month; iv) patients who were allergic to propofol and sevoflurane; and v) patients who had severe heart, liver, or kidney disease. The study was approved by the Ethics Committee of Xiangyang No. 1 People's Hospital Affiliated to Hubei University of Medicine (XY354I; Xiangyang, China). Patients who participated in this research had complete clinical data. All subjects and their parents were informed and agreed to participate in the clinical study. The parents of the child patients signed an informed consent.
Materials and reagents. Scopolamine was purchased from Wantong Pharmaceutical group (Jilin, China) with SFDA approval no. H33021318; promethazine was purchased from Shanghai Harvest Pharmaceutical Co., Ltd. (Shanghai, China) with SFDA approval no. H31021490; fentanyl was purchased from Yichang Humanwell Pharmaceutical Co., Ltd. (Yichang, China) with SFDA approval no. H42022076; etomidate and atracurium were purchased from Jiangsu Hengrui Medicine (Lianyungang, China) with SFDA approval nos. H20090248 and H20060869; propofol was purchased from Fresenius Kabi AB (Beijing, China) with SFDA approval no. J20080023; and sevoflurane was purchased from Lunan Better Pharmaceutical Co., Ltd. (Linyi, China) with SFDA approval no. H20080681. The FITC kits for CD3, CD4, CD8 and CD19 measurements were manufactured by Shanghai BD Biosciences (Shanghai, China). The ELISA kits for TGF- $\beta$, IFN $\gamma$ and IL-4 measurements were manufactured by Shanghai Beyotime Institute of Biotechnology (Shanghai, China).

\section{Anesthesia procedures}

Pre-anesthesia preparation. All pediatric patients underwent $4 \mathrm{~h}$ fasting and $6 \mathrm{~h}$ water-deprivation before operation. Scopolamine $(0.1 \mathrm{mg} / \mathrm{kg})$ and promethazine $(1 \mathrm{mg} / \mathrm{kg})$ were given via intramuscular injection, $30 \mathrm{~min}$ before operation. An intravenous indwelling trocar was placed. The patient was connected to a monitor for checking the vital signs, such as blood pressure and heart rate, during anesthesia.

Anesthesia induction and maintenance. General anesthesia was induced for all patients using $4.5 \mu \mathrm{g} / \mathrm{kg}$ of fentanyl, $0.2 \mathrm{mg} / \mathrm{kg}$ of etomidate and $1.0 \mathrm{mg} / \mathrm{kg}$ of propofol through intravenous injection. In group A, after the indexes of patients before anesthesia were recorded, target-controlled infusion of propofol was performed at a rate of $3 \mu \mathrm{g} / \mathrm{ml}$. In group B, $61 / \mathrm{min}$ of pure oxygen without nitrogen were inhaled for $3 \mathrm{~min}$ using a mask, and after the patient's pulse oximetry $\left(\mathrm{SpO}_{2}\right)$ reached $98 \%$ or more, the patient took several deep breaths as instructed, and then oxygen and $4 \%$ sevoflurane were inhaled at a rate of $6 \mathrm{l} / \mathrm{min}$. Anesthesia in group $\mathrm{C}$ was maintained with propofol given by intravenous infusion at a rate of $2.5 \mathrm{mg} / \mathrm{kg} / \mathrm{h}$ in combination with sevoflurane given by mask inhalation at a concentration of $1 \mathrm{MAC}$. The depth of anesthesia ranged from 40 to 60 in Narcotrend values for all the three groups. Patients were observed for eyelash movement and spontaneous breathing. If necessary, $4.5 \mu \mathrm{g} / \mathrm{kg}$ of fentanyl were given additionally, and anesthesia was maintained by intermittent intravenous infusion of atracurium at a rate of $5 \mu \mathrm{g} / \mathrm{kg} / \mathrm{min}$.

Flow cytometric measurement of T/B-cell subsets. Peripheral venous blood samples (4 $\mathrm{ml}$, heparinized) were drawn, respectively, at $30 \mathrm{~min}$ before anesthesia (T1) and $24 \mathrm{~h}$ after anesthesia (T2). Mononuclear cells (MNC) were separated from the blood samples using density gradient centrifugation at $3,000 \mathrm{x}$ g for $15 \mathrm{~min}$ at $4^{\circ} \mathrm{C}$. MNC were suspended in RPMI-1640 medium supplemented with $10 \%$ fetal bovine serum $\left(1 \times 10^{6} / \mathrm{cells} / \mathrm{ml}\right)$, and then glutamine was added to a final concentration of $2 \mathrm{mmol} / \mathrm{l}$. FITC-labeled mouse anti-human CD3, CD4, CD8, and CD19 monoclonal antibodies (1:100; cat. nos. ab34275, ab59474, ab28010, and ab24936; Abcam, Cambridge, MA,USA) and PE-labeled mouse anti-human IFN $\gamma$ and IL-4 monoclonal antibodies (1:300; cat. nos. 12-7319-42 
Table I. General clinical data of patients in the three groups [n (\%), mean \pm SD].

\begin{tabular}{|c|c|c|c|c|c|}
\hline Variable & Group A $(n=50)$ & Group B $(\mathrm{n}=50)$ & Group C $(\mathrm{n}=50)$ & $\mathrm{F} / \chi^{2}$ & P-value \\
\hline Age (years) & $7.43 \pm 3.76$ & $7.14 \pm 3.19$ & $7.51 \pm 3.55$ & 0.15 & 0.86 \\
\hline \multicolumn{6}{|l|}{ Sex } \\
\hline Male & $23(46)$ & $25(50)$ & $26(52)$ & \multirow[t]{2}{*}{0.37} & \multirow[t]{2}{*}{0.83} \\
\hline Female & $27(54)$ & $25(50)$ & $24(48)$ & & \\
\hline Body weight (kg) & $25.12 \pm 4.73$ & $24.82 \pm 3.91$ & $25.43 \pm 4.11$ & 0.26 & 0.77 \\
\hline BMI $\left(\mathrm{kg} / \mathrm{cm}^{2}\right)$ & $22.86 \pm 3.82$ & $23.81 \pm 4.12$ & $23.87 \pm 4.33$ & 0.95 & 0.39 \\
\hline Lymphoblasts and prolymphocytes (\%) & $55.78 \pm 11.76$ & $58.24 \pm 12.22$ & $56.91 \pm 10.93$ & 0.56 & 0.57 \\
\hline White blood cells $\left(10^{9} /\right.$ liter $)$ & $64.32 \pm 11.43$ & $59.82 \pm 9.78$ & $62.86 \pm 10.98$ & 2.28 & 0.11 \\
\hline Platelets $\left(10^{9} /\right.$ liter $)$ & $54.09 \pm 16.22$ & $57.82 \pm 15.97$ & $53.87 \pm 14.93$ & 1.00 & 0.37 \\
\hline \multicolumn{6}{|l|}{ Immunophenotype } \\
\hline B subtype & $31(62)$ & $28(56)$ & $20(40)$ & \multirow[t]{2}{*}{0.39} & \multirow[t]{2}{*}{0.82} \\
\hline T subtype & $19(38)$ & $22(44)$ & $30(60)$ & & \\
\hline
\end{tabular}

and 12-7049-42; Thermo Fisher Scientific, Inc., Waltham, MA, USA) were added to $100 \mu \mathrm{l}$ of MNC suspension (one kind of antibody/100 $\mu \mathrm{l}$ of MNC suspension), respectively, then incubated for $30 \mathrm{~min}$ at room temperature in the dark, followed by 2 washes with PBS. The cells were fixed by suspension in $2 \%$ paraformaldehyde $(0.5 \mathrm{ml})$ for $30 \mathrm{~min}$. The fixed cells were washed with PBS and re-suspended into $1 \mathrm{ml}$ assay buffer waiting for analysis. The percentages of $\mathrm{CD}^{+}$and $\mathrm{CD}^{+} \mathrm{T}$ cells were measured by flow cytometry (Cell Signaling Technology, Inc., Danvers, MA, USA), and the $\mathrm{CD}^{+} / \mathrm{CD}^{+}$ratio was calculated. The percentages of Th1 $\left(\mathrm{CD}^{+} / \mathrm{IFN} \gamma^{+}\right)$cells and Th2 $\left(\mathrm{CD}^{+} / \mathrm{IL}^{-} 4^{+}\right)$cells in lymphocytes were obtained and the Th1/Th2 ratio was calculated.

ELISA measurement of serum levels of TGF- $\beta, I F N \gamma$ and $I L-4$. The levels of TGF- $\beta$, IFN $\gamma$ and IL-4 (cat. nos. KE00002, KE00063, and KE00016; ProteinTech Group, Inc., Wuhan, China) in peripheral blood serum were measured using ELISA kits in strict accordance with the manufacturer's instructions. Serum was diluted in a ratio of 1:1 with assay buffer and added to the rabbit anti-human monoclonal antibodies (1:300, cat. nos. KE00002, KE00063, and KE00016) pre-coated plate (100 $\mu \mathrm{l} /$ well). The plate was incubated at room temperature for $120 \mathrm{~min}$, followed by 5 washes. After 5 washes, horseradish peroxidase-labeled goat anti-rabbit secondary polyclonal antibody (100 $\mu \mathrm{l} /$ well; cat. nos. SA00001-2; ProteinTech Group, Inc.) was added, and the plate was incubated at room temperature in the dark for $20 \mathrm{~min}$. After adding TMB chromogenic substrate (100 $\mu \mathrm{l} /$ well; Beyotime Institute of Biotechnology), the plate was covered and incubated at room temperature for $20 \mathrm{~min}$. Finally, the reaction was stopped by adding a stop solution ( $50 \mu \mathrm{l} /$ well), and after mixing, the A450 $\mathrm{nm}$ value was measured using a microplate reader (Bio-Rad Laboratories, Inc., Hercules, CA, USA) equipped with a 450-nm filter.

Data processing. Statistical analysis was performed using SPSS 19.0 statistical software (IBM Corp., Armonk, NY, USA). Measurement data were expressed as mean \pm standard deviation (mean \pm SD). Significant differences among three groups were tested by one-way analysis of variance. In case of a significant difference, the LSD-t-test was used to compare significant differences between two groups. Repeated measures analysis of variance was used for comparison at different time points. $\chi^{2}$ test was used for the analysis of enumeration data. $\mathrm{P}<0.05$ was considered to indicate a statistically significant difference.

\section{Results}

General clinical data of patients in the three groups. As shown in Table I, there were no significant differences in age, sex, body weight, BMI, percentage of lymphoblasts and prolymphocytes, white blood cells, platelets, and immunophenotype among the three groups $(\mathrm{P}>0.05)$.

Detection of T-cell subsets in peripheral blood samples. At $\mathrm{T} 1$, there were no significant differences in the percentages of $\mathrm{CD}^{+}, \mathrm{CD}^{+}$, and $\mathrm{CD} 8^{+}$, or in $\mathrm{CD}^{+} / \mathrm{CD}^{+}$ratio among the three groups $(\mathrm{P}>0.05)$. At $\mathrm{T} 2$, the percentages of $\mathrm{CD}^{+}$ and $\mathrm{CD}^{+}$and the $\mathrm{CD} 4^{+} / \mathrm{CD}^{+}$ratios in all groups were significantly increased compared with $\mathrm{T} 1(\mathrm{P}<0.05)$, whereas the percentages of $\mathrm{CD}^{+}$cells were significantly decreased $(\mathrm{P}<0.05)$. At $\mathrm{T} 2$, the percentage of $\mathrm{CD}^{+}$cells in group $\mathrm{B}$ was significantly higher than that in group $\mathrm{A}$, and the percentage of $\mathrm{CD}^{+}$cells in group $\mathrm{C}$ was significantly higher than those in groups $\mathrm{A}$ and $\mathrm{B}(\mathrm{P}<0.05)$. At $\mathrm{T} 2$, there was no significant difference in the percentage of $\mathrm{CD}^{+}$cells between group $\mathrm{B}$ and $\mathrm{A}(\mathrm{P}>0.05)$, and the percentage of $\mathrm{CD} 4^{+}$cells in group $\mathrm{C}$ was significantly higher than those in groups $\mathrm{A}$ and $\mathrm{B}$ $(\mathrm{P}<0.05)$. At $\mathrm{T} 2$, there were no significant differences in the percentage of $\mathrm{CD}^{+}$cells between groups $\mathrm{A}$ and $\mathrm{B}$ or between groups $\mathrm{B}$ and $\mathrm{C}(\mathrm{P}>0.05)$, but the percentage of $\mathrm{CD}^{+}$cells in group $\mathrm{C}$ was significantly higher than that in group $\mathrm{A}$ $(\mathrm{P}<0.05)$. At $\mathrm{T} 2$, there was no significant difference in $\mathrm{CD}^{+} / \mathrm{CD}^{+}$ratio between groups $\mathrm{B}$ and $\mathrm{C}(\mathrm{P}>0.05)$, whereas the $\mathrm{CD} 4^{+} / \mathrm{CD}^{+}$ratios in groups $\mathrm{B}$ and $\mathrm{C}$ were significantly higher than that in group $\mathrm{A}(\mathrm{P}<0.05)$. The detailed results are shown in Table II. 
Table II. Detection of T-cell subsets $\left(\mathrm{CD}^{+}, \mathrm{CD}^{+}{ }^{+}\right.$and $\left.\mathrm{CD} 8^{+}\right)$in peripheral blood (mean $\left.\pm \mathrm{SD}\right)$.

\begin{tabular}{|c|c|c|c|c|c|}
\hline T-cell subset & Group A & Group B & Group C & $\mathrm{F}$ & P-value \\
\hline \multicolumn{6}{|l|}{$\mathrm{CD}^{+}(\%)$} \\
\hline $\mathrm{T} 1$ & $42.98 \pm 5.82$ & $43.82 \pm 6.13$ & $45.31 \pm 7.33$ & 1.67 & 0.19 \\
\hline $\mathrm{T} 2$ & $56.25 \pm 5.91$ & $58.83 \pm 6.11^{\mathrm{a}}$ & $64.32 \pm 6.32^{\mathrm{a}, \mathrm{b}}$ & 22.71 & $<0.001$ \\
\hline $\mathrm{t}$ & 11.31 & 12.26 & 13.89 & & \\
\hline P-value & $<0.001$ & $<0.001$ & $<0.001$ & & \\
\hline \multicolumn{6}{|l|}{$\mathrm{CD}^{+}(\%)$} \\
\hline $\mathrm{T} 1$ & $24.33 \pm 4.82$ & $25.13 \pm 5.12$ & $23.92 \pm 3.19$ & 0.95 & 0.39 \\
\hline $\mathrm{T} 2$ & $33.77 \pm 4.08$ & $35.41 \pm 5.11$ & $39.27 \pm 3.91^{\mathrm{a}, \mathrm{b}}$ & 20.60 & $<0.001$ \\
\hline $\mathrm{t}$ & 10.57 & 10.05 & 21.51 & & \\
\hline P-value & $<0.001$ & $<0.001$ & $<0.001$ & & \\
\hline \multicolumn{6}{|l|}{$\mathrm{CD}^{+}(\%)$} \\
\hline $\mathrm{T} 1$ & $33.78 \pm 6.78$ & $35.86 \pm 5.92$ & $34.11 \pm 6.33$ & 1.55 & 0.22 \\
\hline $\mathrm{T} 2$ & $24.44 \pm 5.22$ & $26.13 \pm 4.91$ & $28.11 \pm 5.39^{\mathrm{a}}$ & 6.30 & $<0.001$ \\
\hline $\mathrm{t}$ & 7.72 & 8.95 & 5.10 & & \\
\hline P-value & $<0.001$ & $<0.001$ & $<0.001$ & & \\
\hline \multicolumn{6}{|l|}{$\mathrm{CD}^{+} / \mathrm{CD}^{+}$} \\
\hline $\mathrm{T} 1$ & $0.72 \pm 0.16$ & $0.75 \pm 0.31$ & $0.69 \pm 0.11$ & 1.09 & 0.37 \\
\hline $\mathrm{T} 2$ & $1.17 \pm 0.21$ & $1.38 \pm 0.33^{\mathrm{a}}$ & $1.43 \pm 0.28^{\mathrm{a}}$ & 12.34 & $<0.001$ \\
\hline $\mathrm{t}$ & 12.05 & 9.84 & 17.39 & & \\
\hline P-value & $<0.001$ & $<0.001$ & $<0.001$ & & \\
\hline
\end{tabular}

${ }^{a} \mathrm{P}<0.05$ vs. group $\mathrm{A} ;{ }^{b} \mathrm{P}<0.05$ vs. group $\mathrm{B}$.

Table III. Detection of B-cell subset $\left(\mathrm{CD} 19^{+}\right)$in peripheral blood samples (mean $\left.\pm \mathrm{SD}\right)$.

\begin{tabular}{lccccc}
\hline CD19+ $(\%)$ & Group A & Group B & Group C & F & P-value \\
\hline $\mathrm{T} 1$ & $9.11 \pm 3.21$ & $10.12 \pm 4.11$ & $9.67 \pm 3.98$ & 0.89 & 0.41 \\
$\mathrm{~T} 2$ & $13.86 \pm 4.31$ & $14.21 \pm 3.21$ & $18.43 \pm 3.87^{\mathrm{a}, \mathrm{b}}$ & 22.13 & $<0.001$ \\
$\mathrm{t}$ & 6.25 & 5.55 & 11.16 & & \\
P-value & $<0.001$ & $<0.001$ & $<0.001$ & &
\end{tabular}

${ }^{\mathrm{a}} \mathrm{P}<0.05$ vs. group $\mathrm{A}$; ${ }^{\mathrm{b}} \mathrm{P}<0.05$ vs. group $\mathrm{B}$.

Detection of B-cell subsets in peripheral blood samples. As shown in Table III, at T1, there was no significant difference in the percentage of $\mathrm{CD} 19^{+}$cells among the three groups $(\mathrm{P}>0.05)$. At $\mathrm{T} 2$, the percentage of $\mathrm{CD} 19^{+}$cells significantly increased in all three groups compared with $\mathrm{T} 1(\mathrm{P}<0.05)$. At $\mathrm{T} 2$, there was no statistical difference in the percentage of $\mathrm{CD} 19^{+}$cells between groups $\mathrm{A}$ and $\mathrm{B}(\mathrm{P}>0.05)$, whereas the percentage of $\mathrm{CD} 19^{+}$cells in group $\mathrm{C}$ was significantly higher than those in groups $\mathrm{A}$ and $\mathrm{B}(\mathrm{P}<0.05)$.

Th1/Th2 ratio in Th cells. The percentages of Th1 and Th2 cells, as well as the ratio of $\mathrm{Th} 1 / \mathrm{Th} 2$, in each group are shown in Table IV and Fig. 1. At T1, there were no significant differences in the percentages of Th1 and Th2 cells, or in the Th1/Th2 ratio among the three groups $(\mathrm{P}>0.05)$. At $\mathrm{T} 2$, the percentages of Th1 and Th 2 cells and the Th1/Th2 ratios were significantly higher in all three groups compared with T1 $(\mathrm{P}<0.05)$. At $\mathrm{T} 2$, the percentage of Th1 cells in group B was higher than that in group A, and the percentages of Th1 and $\mathrm{Th} 2$ cells in group $\mathrm{C}$ were higher than those in groups $\mathrm{A}$ and $\mathrm{B}$ $(P<0.05)$. There was no significant difference in the percentage of Th2 cells between groups A and B ( $>>0.05)$. The Th1/Th2 ratio in group $\mathrm{C}$ was higher than those in groups $\mathrm{A}$ and $\mathrm{B}$ $(\mathrm{P}<0.05)$, whereas there was no significant difference between groups $\mathrm{A}$ and $\mathrm{B}(\mathrm{P}>0.05)$.

Serum levels of TGF- $\beta$, IFN $\gamma$ and IL-4, and IFN $/ I L-4$ ratio. The serum levels of TGF- $\beta$, IFN $\gamma$ and IL- 4 , as well as the IFN $\gamma / \mathrm{IL}-4$ ratio in each group are shown in Table V and Fig. 2. At T1, there were no significant differences in the serum levels of TGF- $\beta$, IFN $\gamma$ and IL- 4 and in IFN $\gamma /$ IL- 4 ratio among the three groups $(\mathrm{P}>0.05)$. At $\mathrm{T} 2$, the serum levels of IFN $\gamma$ and IL-4, and 
Table IV. Th1/Th2 ratio in Th cells (mean $\pm \mathrm{SD})$.

\begin{tabular}{|c|c|c|c|c|c|}
\hline Th cell & Group A & Group B & Group C & $\mathrm{F}$ & P-value \\
\hline \multicolumn{6}{|l|}{ Th1 (\%) } \\
\hline $\mathrm{T} 1$ & $32.98 \pm 5.82$ & $33.82 \pm 6.13$ & $35.31 \pm 7.33$ & 1.67 & 0.19 \\
\hline $\mathrm{T} 2$ & $56.25 \pm 5.91$ & $58.83 \pm 6.11^{\mathrm{a}}$ & $64.32 \pm 6.32^{\mathrm{a}, \mathrm{b}}$ & 22.71 & $<0.001$ \\
\hline $\mathrm{t}$ & 11.31 & 12.26 & 13.89 & & \\
\hline P-value & $<0.001$ & $<0.001$ & $<0.001$ & & \\
\hline \multicolumn{6}{|l|}{ Th2 (\%) } \\
\hline $\mathrm{T} 1$ & $24.33 \pm 4.82$ & $25.13 \pm 5.12$ & $23.92 \pm 3.19$ & 0.95 & 0.39 \\
\hline $\mathrm{T} 2$ & $33.77 \pm 4.08$ & $35.41 \pm 5.11$ & $39.27 \pm 3.91^{\mathrm{a}, \mathrm{b}}$ & 20.60 & $<0.001$ \\
\hline $\mathrm{t}$ & 10.57 & 10.05 & 21.51 & & \\
\hline P-value & $<0.001$ & $<0.001$ & $<0.001$ & & \\
\hline \multicolumn{6}{|l|}{ Th1/Th2 } \\
\hline $\mathrm{T} 1$ & $1.24 \pm 0.22$ & $1.13 \pm 0.41$ & $1.11 \pm 0.39$ & 1.99 & 0.14 \\
\hline $\mathrm{T} 2$ & $2.48 \pm 0.58$ & $2.46 \pm 0.52$ & $2.81 \pm 0.33^{\mathrm{a}, \mathrm{b}}$ & 8.09 & $<0.001$ \\
\hline $\mathrm{t}$ & 14.13 & 14.20 & 23.53 & & \\
\hline P-value & $<0.001$ & $<0.001$ & $<0.001$ & & \\
\hline
\end{tabular}

${ }^{\mathrm{a}} \mathrm{P}<0.05$ vs. group $\mathrm{A}$; ${ }^{\mathrm{b}} \mathrm{P}<0.05$ vs. group $\mathrm{B}$. Th cells, T helper cells.

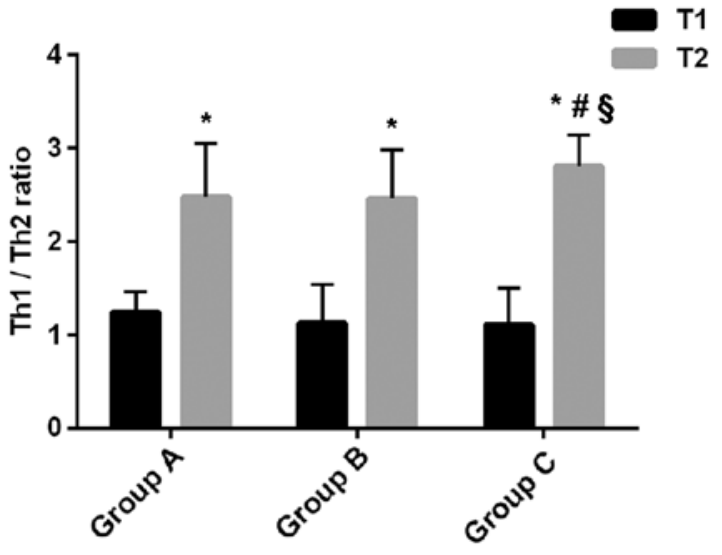

Figure 1. Ratio of Th1/Th2. At T1, there was no significant difference in Th1/Th2 ratio among the three groups $(\mathrm{P}>0.05)$. At $\mathrm{T} 2, \mathrm{Th} 1 / \mathrm{Th} 2$ ratios were significantly higher in all three groups, compared with $\mathrm{T} 1\left({ }^{*} \mathrm{P}<0.05\right)$. At $\mathrm{T} 2$, there was no significant difference in Th1/Th2 ratio between groups $A$ and $B$ $(\mathrm{P}>0.05)$, whereas the Th1/Th2 ratio in group $\mathrm{C}$ was significantly higher than those in groups $\mathrm{A}\left({ }^{*} \mathrm{P}<0.05\right)$ and $\mathrm{B}\left({ }^{\circledR} \mathrm{P}<0.05\right)$. Th cells, T helper cells.

the IFN $\gamma /$ IL-4 ratios significantly increased, compared with T1, whereas the level of TGF- $\beta$ significantly decreased $(\mathrm{P}<0.05)$ in all the groups. At T2, the TGF- $\beta$ level in group $C$ was significantly higher than that in group $\mathrm{A}(\mathrm{P}<0.05)$, whereas there was no significant difference in TGF- $\beta$ level between groups $A$ and $\mathrm{B}$, or between group $\mathrm{B}$ and $\mathrm{C}(\mathrm{P}>0.05)$. The IFN $\gamma$ level in group $\mathrm{B}$ was higher than that in group $\mathrm{A}$, and in group $\mathrm{C}$ was higher than those in groups $\mathrm{A}$ and $\mathrm{B}(\mathrm{P}<0.05)$. At $\mathrm{T} 2$, there was no significant difference in IL-4 level between groups A and B, whereas the IL-4 level in group $C$ was higher than those in groups $\mathrm{A}$ and $\mathrm{B}(\mathrm{P}<0.05)$. At $\mathrm{T} 2$, there was no significant difference in IFN $\gamma / \mathrm{IL}-4$ ratio between groups $\mathrm{A}$ and $\mathrm{B}$, as well as between groups $\mathrm{B}$ and $\mathrm{C}(\mathrm{P}>0.05)$, whereas the IFN $\gamma / \mathrm{IL}-4$ ratio in group $\mathrm{C}$ was higher than that in group $\mathrm{A}(\mathrm{P}<0.05)$.

\section{Discussion}

ALL is a malignant clonal disease of lymphoid progenitor cells characterized by the presence of a large number of prolymphocytes that interfere with the production of new red blood cells, white blood cells and platelets (16). At present, anesthesia or sedation is required in the diagnosis and treatment of ALL (17). For pediatric and adolescent patients, analgesia and sedation can prevent emotional distress caused by a painful operation, thus improving operation quality (18). The outcome of anesthesia and sedation, including the effect on immune function of pediatric patients with ALL, is closely associated with the prognosis (19). Mozhaev et al (19) have reported that combined epidural-general anesthesia can effectively reduce the effect of T-cell immune function on postoperative cognitive function in patients with esophageal cancer. In this study, the effect of combined propofol-sevoflurane anesthesia on the immune function of pediatric patients with ALL was explored, aiming at improving the efficacy and safety of anesthesia, as well as the prognosis and the survival rate of these patients.

Group A received propofol anesthesia, group B received sevoflurane anesthesia, and group $\mathrm{C}$ received combined propofol-sevoflurane anesthesia. There were no significant differences in the general clinical data, such as, age, sex, body weight, BMI, percentage of lymphoblasts and prolymphocytes, white blood cells, platelets, and immunophenotype among the three groups. The percentages of lymphoblasts and prolymphocytes were $>30 \%$ in all groups, meeting the diagnostic criteria of $\mathrm{ALL} \mathrm{CD}^{+}$is a common surface marker of $\mathrm{T}$ cells, $\mathrm{CD}^{+}$is a surface marker of Th cells, and $\mathrm{CD}^{+}$is a surface marker of cytotoxic T lymphocytes (CTL). A high ratio of $\mathrm{CD}^{+} / \mathrm{CD}^{+}$ represents relatively strong autoimmune function (20). CD19 ${ }^{+}$ is expressed on the surface of B lymphocytes (21). By measurement of T-cell subsets in peripheral blood, it was found 
Table V. Serum levels of TGF- $\beta$, IFN $\gamma$ and IL-4 and IFN $\gamma / \mathrm{IL}-4$ ratio (mean \pm SD).

\begin{tabular}{|c|c|c|c|c|c|}
\hline Variable & Group A & Group B & Group C & $\mathrm{F}$ & P-value \\
\hline \multicolumn{6}{|c|}{ TGF- $\beta$ (ng/ml) } \\
\hline $\mathrm{T} 1$ & $2.34 \pm 0.51$ & $2.21 \pm 0.36$ & $2.36 \pm 0.58$ & 1.37 & 0.26 \\
\hline $\mathrm{T} 2$ & $1.76 \pm 0.34$ & $1.62 \pm 0.42$ & $1.49 \pm 0.44^{\mathrm{a}}$ & 5.63 & $<0.001$ \\
\hline $\mathrm{t}$ & 6.69 & 7.54 & 8.45 & & \\
\hline P-value & $<0.001$ & $<0.001$ & $<0.001$ & & \\
\hline \multicolumn{6}{|c|}{$\operatorname{IFN} \gamma(\mathrm{ng} / \mathrm{ml})$} \\
\hline $\mathrm{T} 1$ & $130.33 \pm 6.82$ & $131.13 \pm 5.12$ & $128.92 \pm 4.19$ & 2.08 & 0.12 \\
\hline $\mathrm{T} 2$ & $151.44 \pm 4.08$ & $146.41 \pm 5.11^{\mathrm{a}}$ & $178.92 \pm 6.91^{\mathrm{a}, \mathrm{b}}$ & 20.60 & $<0.001$ \\
\hline $\mathrm{t}$ & 18.78 & 14.94 & 43.75 & & \\
\hline P-value & $<0.001$ & $<0.001$ & $<0.001$ & & \\
\hline \multicolumn{6}{|c|}{ IL-4 (ng/ml) } \\
\hline $\mathrm{T} 1$ & $34.92 \pm 6.78$ & $35.43 \pm 6.11$ & $34.96 \pm 5.78$ & 0.10 & 0.90 \\
\hline $\mathrm{T} 2$ & $44.44 \pm 5.31$ & $46.11 \pm 4.781$ & $46.11 \pm 5.22^{\mathrm{a}, \mathrm{b}}$ & 12.21 & $<0.001$ \\
\hline $\mathrm{t}$ & 5.35 & 6.09 & 10.12 & & \\
\hline P-value & $<0.001$ & $<0.001$ & $<0.001$ & & \\
\hline \multicolumn{6}{|l|}{ IFN $\gamma / \mathrm{IL}-4$} \\
\hline $\mathrm{T} 1$ & $1.11 \pm 0.42$ & $1.13 \pm 0.71$ & $1.15 \pm 0.99$ & 3.29 & 0.04 \\
\hline $\mathrm{T} 2$ & $2.78 \pm 0.48$ & $2.86 \pm 0.32$ & $2.91 \pm 0.33^{\mathrm{a}}$ & 1.91 & 0.15 \\
\hline $\mathrm{t}$ & 3.66 & 2.45 & 9.08 & & \\
\hline P-value & $<0.001$ & 0.01 & $<0.001$ & & \\
\hline
\end{tabular}

${ }^{\mathrm{a}} \mathrm{P}<0.05$ vs. group $\mathrm{A} ;{ }^{\mathrm{b}} \mathrm{P}<0.05$ vs. group $\mathrm{B}$.

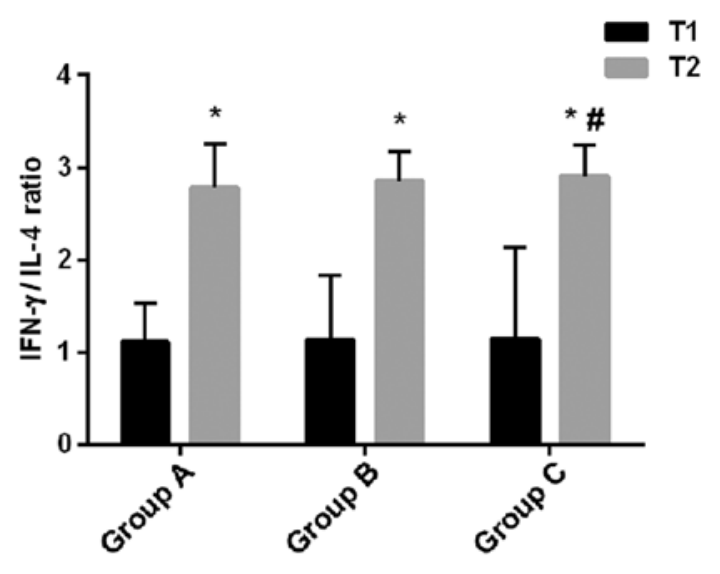

Figure 2. Ratio of IFN $\gamma /$ IL-4. At T1, there was no significant difference in IFN $\gamma / \mathrm{IL}-4$ ratio among the three groups $(\mathrm{P}>0.05)$. At T2, IFN $\gamma / \mathrm{IL}-4$ ratios were significantly higher in all three groups compared with $\mathrm{T} 1\left({ }^{*} \mathrm{P}<0.05\right)$. At $\mathrm{T} 2$, there was no significant difference in IFN $\gamma / \mathrm{IL}-4$ ratio between groups $\mathrm{A}$ and $\mathrm{B}$, or between groups $\mathrm{B}$ and $\mathrm{C}(\mathrm{P}>0.05)$, whereas the IFN $\gamma / \mathrm{IL}-4$ ratio in group $\mathrm{C}$ was higher than that in group $\mathrm{A}\left({ }^{*} \mathrm{P}<0.05\right)$.

that there were no significant differences in the percentages of $\mathrm{CD}^{+}, \mathrm{CD}^{+}, \mathrm{CD}^{+}$, and $\mathrm{CD} 19^{+}$cells and in $\mathrm{CD} 4^{+} / \mathrm{CD}^{+}$ratio among the three groups before anesthesia. After anesthesia and chemotherapy, the percentages of $\mathrm{CD}^{+}, \mathrm{CD}^{+}$and $\mathrm{CD} 19^{+}$cells and the ratios of $\mathrm{CD}^{+} / \mathrm{CD}^{+}$in all three groups became significantly higher than those before anesthesia, whereas the percentages of $\mathrm{CD}^{+}$cells became significantly lower. These findings suggest that the activity of T/B-cell subsets in each group is improved after chemotherapy. The results from between-group comparisons further indicate that combined propofol-sevoflurane anesthesia is more beneficial to the recovery of immune function, by restoring the activity of T/B cell subsets, compared with propofol only or sevoflurane only. In a study on the effects of combined sevoflurane-fentanyl or propofol-fentanyl on the immune function in patients with colorectal cancer, Viallard et al (22) reported that the percentages of $\mathrm{CD}^{+}$cells in both groups decreased from $2 \mathrm{~h}$ after operation, compared with those before anesthesia. The percentage of $\mathrm{CD}^{+}$cells in combined propofol-fentanyl group increased $24 \mathrm{~h}$ after operation, which was obviously higher than that in the combined sevoflurane-fentanyl group. Compared with those before anesthesia, the postoperative percentages of $\mathrm{CD}^{+}$cells increased significantly in both groups. The ratio of $\mathrm{CD}^{+} / \mathrm{CD}^{+}$decreased from 2 to $24 \mathrm{~h}$ after operation, and at each time-point the ratio of $\mathrm{CD}^{+} / \mathrm{CD}^{+}$ in the combined propofol-fentanyl group was significantly higher than that in the combined sevoflurane-fentanyl group $(\mathrm{P}<0.05)$. The percentage of $\mathrm{CD}^{+}$cells in the combined propofol-fentanyl group was significantly higher at $24 \mathrm{~h}$ after operation than that at the end of operation. Apparently, there is a discrepancy between the findings of Viallard et al (22) and the results of the present study. This might be due to the different treatment options followed in the two studies, and also because combined propofol-sevoflurane anesthesia was used in the present study.

At T1, there were no significant differences in the percentages of Th1 and Th2 cells, and in Th1/Th2 ratio among the 
three groups. At T2, compared with $\mathrm{T} 1$, the percentages of Th1 and Th2 cells and the Th1/Th2 ratios were significantly higher in all three groups. $\mathrm{CD}^{+}$cells are mainly Th cells, which can differentiate into Th1 and Th2 cells. CD8 ${ }^{+}$cells are mainly cytotoxic $\mathrm{T}$ cells and suppressor $\mathrm{T}$ cells (23). Therefore, the percentages of Th1 and Th2 cells increase along with the increase of the percentage of $\mathrm{CD}^{+} \mathrm{T}$ cells. This is consistent with the results of $\mathrm{T} / \mathrm{B}$-cell subsets measurements in this study. Th1/Th2 ratio increased significantly, indicating that the Th1/Th2 balance drifted to Th1 after anesthesia and chemotherapy. Chemotherapy relieved the body's state of immunosuppression. Studies have shown that in tumor patients, tumor cells can escape from the body's immune response. Th2 cells secrete more cytokines, such as IL-4 and IL-10, causing an imbalance in Th1/Th2 ratio $(24,25)$. At $\mathrm{T} 2$, the Th1/Th2 ratio in group $\mathrm{C}$ was higher than those in groups $\mathrm{A}$ and $\mathrm{B}$. This finding suggests that combined propofol-sevoflurane anesthesia is more beneficial in alleviating immunosuppression, compared with propofol only or sevoflurane only.

In comparison of serum levels of TGF- $\beta$, IFN $\gamma$ and IL-4 and the ratio of IFN $\gamma / \mathrm{IL}-4$, it was found that at T2 the serum levels of IFN $\gamma$ and IL- 4 and the ratios of IFN $\gamma / \mathrm{IL}-4$ were all higher, while the levels of TGF- $\beta$ were lower than those at T1 in all the three groups. TGF- $\beta$ is a tumor immunosuppressive factor that promotes the growth of tumor cells, and a decrease in TGF- $\beta$ expression indicates an enhanced suppression of tumor cell growth (26). The ratio of IFN $\gamma / \mathrm{IL}-4$ is an index of Th1/Th2 cell balance, because Th1 cells mainly secrete pro-inflammatory factors, such as IFN $\gamma$, and Th2 cells mainly secrete anti-inflammatory factors, such as IL-4 (27). Therefore, the above-mentioned findings suggest that tumor growth is suppressed after anesthesia and chemotherapy. The serum level of TGF- $\beta$ and the ratio of IFN $\gamma / \mathrm{IL}-4$ were higher in group $\mathrm{C}$ than those in group $\mathrm{A}$, suggesting that combined propofol-sevoflurane anesthesia is more beneficial to the suppression of tumor progression, compared with propofol only. However, there are certain limitations in the present investigation. The specific mechanism of propofol combined with sevoflurane anesthesia was not investigated. Also, the sample size should be increased to further explore the role of propofol combined with sevoflurane anesthesia.

In summary, combined propofol-sevoflurane anesthesia is more conducive to the recovery of T/B-cell subsets activity, the alleviation of immunosuppression, and the suppression of ALL progression, compared with propofol only or sevoflurane only.

\section{Acknowledgements}

Not applicable.

\section{Funding}

No funding was received.

\section{Availability of data and materials}

The datasets used and/or analyzed during the current study are available from the corresponding author on reasonable request.

\section{Authors' contributions}

NiD and YG assisted with flow cytometry. NaD performed ELISA. NiD drafted the manuscript. All authors read and approved the final manuscript.

\section{Ethics approval and consent to participate}

This study was approved by the Ethics Committee of Xiangyang No. 1 People's Hospital Affiliated to Hubei University of Medicine (Xiangyang, China). Patients who participated in this research had complete clinical data. The parents of the child patients signed an informed consent.

\section{Patient consent for publication}

Not applicable.

\section{Competing interests}

The authors declare that they have no competing interests.

\section{References}

1. Altenburg JD, Harvey KA, McCray S, Xu Z and Siddiqui RA: A novel 2,6-diisopropylphenyl-docosahexaenoamide conjugate induces apoptosis in T cell acute lymphoblastic leukemia cell lines. Biochem Biophys Res Commun 411: 427-432, 2011.

2. Bertolizio G, Stucchi R, Sahillioglu E, Somaini M, Dander E, Biondi A, Jankovic M, D'Amico G and Ingelmo PM: The effects of propofol and ketamine on the cytokine levels of children with acute lymphoblastic leukemia. J Pediatr Hematol Oncol 35: e296-e300, 2013.

3. Luczyński W, Stasiak-Barmuta A, Krawczuk-Rybak M, Malinowska I, Matysiak M, Mitura-Lesiuk M, Kowalczyk J and Jeromin A: Th1/Th2 balance in acute lymphoblastic leukemia in children. Przegl Lek 61: 919-923, 2004 (In Polish).

4. Moorman AV, Harrison CJ, Buck GA, Richards SM, Secker-Walker LM, Martineau M, Vance GH, Cherry AM, Higgins RR, Fielding AK, et al; Adult Leukaemia Working Party, Medical Research Council/National Cancer Research Institute: Karyotype is an independent prognostic factor in adult acute lymphoblastic leukemia (ALL): Analysis of cytogenetic data from patients treated on the Medical Research Council (MRC) UKALLXII/Eastern Cooperative Oncology group (ECOG) 2993 trial. Blood 109: 3189-3197, 2007.

5. Nicolini FE, Mauro MJ, Martinelli G, Kim DW, Soverini S, Müller MC, Hochhaus A, Cortes J, Chuah C, Dufva IH, et al: Epidemiologic study on survival of chronic myeloid leukemia and $\mathrm{Ph}\left({ }^{+}\right)$acute lymphoblastic leukemia patients with BCR-ABL T315I mutation. Blood 114: 5271-5278, 2009.

6. Glaisyer HR and Sury MR: Recovery after anesthesia for short pediatric oncology procedures: Propofol and remifentanil compared with propofol, nitrous oxide, and sevoflurane. Anesth Analg 100: 959-963, 2005.

7. Hajdenberg J, Grote T, Yee L, Arevalo-Araujo R and Latimer LA: Infusion of palonosetron plus dexamethasone for the prevention of chemotherapy-induced nausea and vomiting. J Support Oncol 4: 467-471, 2006.

8. Maurizi P, Russo I, Rizzo D, Chiaretti A, Coccia P, Attinà G, Ruggiero A and Riccardi R: Safe lumbar puncture under analgo-sedation in children with acute lymphoblastic leukemia. Int J Clin Oncol 19: 173-177, 2014.

9. Godambe SA, Elliot V, Matheny D and Pershad J: Comparison of propofol/fentanyl versus ketamine/midazolam for brief orthopedic procedural sedation in a Pediatric Emergency Department. Pediatrics 112: 116-123, 2003.

10. Chiaretti A, Ruggiero A, Barone G, Antonelli A, Lazzareschi I, Genovese O, Paiano S, Sammartino M, Maurizi P and Riccardi R: Propofol/alfentanil and propofol/ketamine procedural sedation in children with acute lymphoblastic leukaemia: Safety, efficacy and their correlation with pain neuromediator expression. Eur J Cancer Care (Engl) 19: 212-220, 2010. 
11. Lim JA, Oh CS, Yoon TG, Lee JY, Lee SH, Yoo YB, Yang JH and Kim SH: The effect of propofol and sevoflurane on cancer cell, natural killer cell, and cytotoxic T lymphocyte function in patients undergoing breast cancer surgery: An in vitro analysis. BMC Cancer 18: 159, 2018.

12. Chen Y, Liang M, Zhu Y and Zhou D: The effect of propofol and sevoflurane on the perioperative immunity in patients under laparoscopic radical resection of colorectal cancer. Zhonghua Yi Xue Za Zhi 95: 3440-3444, 2015 (In Chinese).

13. Whitlow PG, Saboda K, Roe DJ, Bazzell S and Wilson C: Topical analgesia treats pain and decreases propofol use during lumbar punctures in a randomized pediatric leukemia trial. Pediatr Blood Cancer 62: 85-90, 2015.

14. Tan R: Effect of propofol and isoflurane on surgical stress response and postoperative cognitive function in elderly patients. Nan Fang Yi Ke Da Xue Xue Bao 29: 1247-1248, 2009 (In Chinese).

15. Flouda L, Pandazi A, Papageorgiou C, Perrea D, Krepi E and Kostopanagiotou G: Comparative effects of sevoflurane and propofol based general anaesthesia for elective surgery on memory. Arch Med Sci 9: 105-111, 2013.

16. Piotrowski AJ and Fendler WM: Hyperkalemia and cardiac arrest following succinylcholine administration in a 16-year-old boy with acute nonlymphoblastic leukemia and sepsis. Pediatr Crit Care Med 8: 183-185, 2007.

17. Panwar P, Singh S, Kumar N, Rawat H and Mishra AK: Synthesis, characterization, and in vivo skeletal localization of a new $(99 \mathrm{~m})$ Tc-based multidentate phosphonate chelate: 5-Amino-1,3-bis(eth ylamine-(N,N dimethyl diphosphonic acid) acetamido) benzene. Bioorg Med Chem 15: 1138-1145, 2007.

18. Neuhäuser C, Wagner B, Heckmann M, Weigand MA and Zimmer KP: Analgesia and sedation for painful interventions in children and adolescents. Dtsch Arztebl Int 107: 241-247, I-II, I, 2010.

19. Mozhaev GA and Kraevaia SB: Non-specific cellular immunity in tonsillectomies in children under general anesthesia. Anesteziol Reanimatol 4: 36-39, 1981 (In Russian).
20. Kwak Y, Koh J, Kim DW, Kang SB, Kim WH and Lee HS: Immunoscore encompassing $\mathrm{CD}^{+}$and $\mathrm{CD}^{+} \mathrm{T}$ cell densities in distant metastasis is a robust prognostic marker for advanced colorectal cancer. Oncotarget 7: 81778-81790, 2016.

21. Zhang Y, Zhang X, Xia Y, Jia X, Li H, Zhang Y, Shao Z, Xin N, Guo M, Chen J, et al: CD19+ Tim- $^{+}{ }^{+} \mathrm{B}$ cells are decreased and negatively correlated with disease severity in Myasthenia Gravis patients. Immunol Res 64: 1216-1224, 2016.

22. Viallard JF, Pellegrin JL, Ranchin V, Schaeverbeke T, Dehais J, Longy-Boursier M, Ragnaud JM, Leng B and Moreau JF: Th1 (IL-2, interferon-gamma (IFN-gamma)) and Th2 (IL-10, IL-4) cytokine production by peripheral blood mononuclear cells (PBMC) from patients with systemic lupus erythematosus (SLE). Clin Exp Immunol 115: 189-195, 1999.

23. Ziegler A, Heidenreich R, BraumüllerH, Wolburg H, Weidemann S, Mocikat R and Röcken M: EpCAM, a human tumor-associated antigen promotes Th2 development and tumor immune evasion. Blood 113: 3494-3502, 2009.

24. Xia N, Zhou S, Liang Y, Xiao C, Shen H, Pan H, Deng H, Wang $\mathrm{N}$ and Li QQ: CD4 ${ }^{+} \mathrm{T}$ cells and the Th1/Th2 imbalance are implicated in the pathogenesis of Graves' ophthalmopathy. Int J Mol Med 17: 911-916, 2006.

25. Gore AJ, Deitz SL, Palam LR, Craven KE and Korc M: Pancreatic cancer-associated retinoblastoma 1 dysfunction enables TGF- $\beta$ to promote proliferation. J Clin Invest 124: 338-352, 2014.

26. Hattori K, Nishikawa M, Watcharanurak K, Ikoma A, Kabashima K, Toyota H, Takahashi Y, Takahashi R, Watanabe Y and Takakura Y: Sustained exogenous expression of therapeutic levels of IFN-gamma ameliorates atopic dermatitis in NC/Nga mice via Th1 polarization. J Immunol 184: 2729-2735, 2010.

27. Li AL, Ma DX and Meng XC: Effect of lactobacilli on Th1/Th2 cells balance in primary lymphocytes. Xi Bao Yu Fen Zi Mian Yi Xue Za Zhi 27: 389-391, 394, 2011 (In Chinese).

(7) $\odot$ This work is licensed under a Creative Commons c) Attribution-NonCommercial-NoDerivatives 4.0 International (CC BY-NC-ND 4.0) License. 